\section{Growth and Challenges in Florida's Environmental Horticulture Industry}

\author{
Alan W. Hodges ${ }^{1,3}$ and John J. Haydu ${ }^{2}$
}

ADDITIONAL INDEX WORDs. economic impact, multipliers, output, employment, value added, IMPLAN, economic region, wholesale plant nurseries, landscape services, horticultural retailers, marketing, hurricanes

Summary. Total Florida environmental horticulture industry sales in 2005 were $\$ 15.24$ billion (B), whereas total industry output amounted to \$10.39 B with $\$ 3.01 \mathrm{~B}$ for wholesale nurseries, $\$ 5.25 \mathrm{~B}$ for landscape services, and \$2.13 B for horticultural retailers, which reflects the average gross margin on retail sales. Direct employment in the industry was 190,000 full-time jobs plus nearly 104,000 temporary, part-time, or seasonal jobs. Total employment impacts were 319,000 full-time and part-time/seasonal jobs, including 24,000 jobs created in other sectors of the economy. Total value-added or income impacts of $\$ 8.65 \mathrm{~B}$ included $\$ 5.19 \mathrm{~B}$ in labor income for employee wages, salaries, and business owner (proprietor) income. Fiscal impacts included $\$ 549$ million $(M)$ in indirect business taxes paid to local and state governments. Results for 2005 compared with previous studies performed for 1997 and 2000 indicate that growth in the industry has been dramatic over this time period. Industry sales increased from $\$ 8.35 \mathrm{~B}$ in 1997 to $\$ 15.24 \mathrm{~B}$ in 2005 , representing a $7.8 \%$ average annual compound growth rate, whereas employment impacts grew at a $9.2 \%$ annual rate, and value-added impacts grew by $4.7 \%$. The study also evaluated the impacts to the industry from eight hurricanes that struck Florida during 2004 and 2005. Nearly $80 \%$ of surveyed firms were adversely impacted by at least one hurricane. Total damages and losses resulting from hurricanes were estimated at $\$ 2.12 \mathrm{~B}$, including product (crop) losses of $\$ 1.05 \mathrm{~B}$, structural damages of $\$ 465 \mathrm{M}$, and cleanup costs of $\$ 605 \mathrm{M}$. Product losses of at least $\$ 100,000$ were sustained by $\mathbf{2 2 \%}$ of firms, whereas structural damages and cleanup costs of this level were suffered by $12 \%$ and $8 \%$ of firms, respectively. Nearly half $(48 \%)$ of the firms had their business interrupted for 3 weeks or more. Despite these large losses, the industry continues to thrive.

$\mathrm{T}$ he environmental horticulture or "green" industry encompasses a wide range of businesses, including wholesale nursery and greenhouse producers, lawn and garden supply and equipment manufacturing, landscape design, installation and maintenance services, lawn and garden stores, and other retail establishments selling plants and related lawn and garden goods. In terms of overall industry value, Florida is a leading state, ranked second only to California in the United States. According to a recent study for 2002, Florida's green industry had

This research project was sponsored by the Florida Nursery, Growers and Landscape Association; the Tampa Bay Wholesale Growers Association; and AgFirst/Farm Credit Bank of Florida. Telephone surveys were conducted by the University of Florida, Bureau of Economic and Business Research.

${ }^{1}$ University of Florida, Institute of Food and Agricultural Sciences, Food and Resource Economics Department, Gainesville, FL 32611

${ }^{2}$ University of Florida, Institute of Food and Agricultural Sciences, Mid-Florida Research and Education Center, Apopka, FL 32703

${ }^{3}$ Corresponding author. E-mail: awhodges@ufl.edu. total employment impacts of 147,795 jobs, output impacts of $\$ 10.0$ billion (B), and value-added impacts of \$7.1 B (Hall et al., 2006). These results represented significant increases in Florida since previous studies were completed for 1997 and 2000 (Hodges and Haydu, 2000, 2002).

Ornamental plants are one of the largest agricultural commodity groups in Florida along with fruits, vegetables, and forest products (Hodges and Mulkey, 2006). According to the Census of Agriculture for 2002, the state of Florida had over $4500 \mathrm{com}$ mercial nursery and greenhouse farms with production area of 119,000 acres in the open and 361 million $\mathrm{ft}^{2}$ under glass or other protective cover, total sales of $\$ 1.82 \mathrm{~B}$, and capital assets in land, buildings, and equipment averaging $\$ 610,000$ per farm [U.S. Dept. of Agriculture (USDA), 2004]. According to official USDA time series statistics (Jerardo, 2005), Florida nursery and greenhouse sales over the past decade have grown by $25 \%$ in inflation-adjusted terms, representing an annual growth rate of $2.5 \%$.

The environmental horticulture industry in Florida has experienced significant negative impacts from natural disasters affecting the production and sale of many nursery products. In 1999 and 2000, a severe drought in Florida resulted in decreased sales of $\$ 245$ million $(\mathrm{M})$ by nursery and landscape firms resulting from restricted water allocations (Hodges and Haydu, 2002). In 2004 and 2005, Florida was struck by eight named hurricanes, causing major damage in all parts of the state.

The present study was undertaken to evaluate the economic impact of Florida's environmental horticulture industry for 2005 using methods similar to those used in the two previous studies to facilitate comparisons of industry performance and economic values over time and also to evaluate the financial impacts of the hurricanes in 2004 to 2005 .

\section{Methods}

S UR V E Y D E S I G N A N D IMPLEMENTATION. Estimation of the economic value of Florida's environmental horticultural industry was based on information obtained from telephone and Internet surveys of nursery producers, landscape service firms, and horticultural retailers conducted in late 2005 and early 2006. Separate questionnaires were used for each industry sector. Information was collected on sales in 2005 , employment, types of goods or services offered, regional trade, types of customers or market outlets, marketing practices used, threats to the industry along with crop losses, structural damages to buildings and equipment, repair/cleanup costs, and length of business interruption resulting from

\begin{tabular}{llll}
\hline $\begin{array}{l}\text { Units } \\
\begin{array}{l}\text { To convert U.S. to SI, } \\
\text { multiply by }\end{array}\end{array}$ & U.S. unit & SI unit & $\begin{array}{l}\text { To convert SI to U.S., } \\
\text { multiply by }\end{array}$ \\
\hline 0.4047 & acre(s) & $\mathrm{ha}$ & 2.4711 \\
0.0929 & $\mathrm{ft}^{2}$ & $\mathrm{~m}^{2}$ & 10.7639
\end{tabular}


hurricanes in 2004 and 2005. Information on annual sales was collected as a specific value, or within a range of values offered, at the discretion of the respondent to avoid disclosure of sensitive data.

An Internet survey of the members of the Florida Nursery, Growers and Landscape Association was conducted in Dec. 2005 and Jan. 2006. A total of 907 firms were contacted by e-mail and provided with an electronic link to the web site survey service that automatically administered the survey, tracked respondents, and recorded responses (Survey Monkey, Portland, OR). Each firm was directed to the appropriate survey questionnaire based on its primary activity. Recent research has demonstrated that Internet surveys generally produce results that are as reliable and representative as traditional mail or telephone surveys (Berrens et al., 2003). Both Internet and telephone surveys were used to enhance response rates and reduce overall time required for survey administration.

A separate telephone survey of the general population of environmental horticulture businesses in Florida was conducted during Mar. and Apr. 2006. The telephone interviews were done under subcontract by the University of Florida, Bureau of Economic and Business Research, using a computer-assisted system to dial telephone numbers, generate questions, and record respondents' answers, and information on interview time/date and the disposition of all calls. Firms contacted for this survey were drawn in random order from the population lists with those responding to the Internet survey removed to avoid duplication of responses. All firms participating in the survey were qualified as having produced or sold ornamental plants, landscape services, or horticultural goods in 2005, and the individual respondent was qualified as being knowledgeable about the general business practices and management of the company. In some cases, repeated attempts were made to contact a qualified respondent. Listings of firms for the telephone survey were obtained from a variety of sources. For nurseries and horticultural retailers, a list obtained from the Florida Department of Agriculture-Division of Plant Industry included all firms that are registered to produce or sell plant products. Nursery firms having a plant inventory of at least 1000 units were considered to be bona fide commercial firms for this study. A listing of Florida landscape services businesses was obtained from a Dun and Bradstreet database based on Standard Industrial Classification codes.
The overall population of industry firms included 4477 nurseries, 7359 retailers (stock dealers), and 8440 landscape services firms.

Survey responses were received from 838 firms, including 434 nurseries, 191 landscape service firms, and 213 horticultural retailers (Table 1). These responses represented 9.7\%, $2.3 \%$, and $2.9 \%$ of the population, respectively. The Internet survey produced 250 responses and the telephone survey provided 588 responses. For the telephone survey, a total of 6917 calls were attempted, of which $8.5 \%$ were completed or partially completed, $11.8 \%$ were refused, $22.5 \%$ had no answer, busy signal, answering machine, technical problems, or a qualified respondent was not available. Overall, some $57.2 \%$ of firms called were considered ineligible for the survey as a result of nonworking numbers, fax lines, number changed, no eligible respondent, and so on.

SURVEY ANALYSIS AND ECONOMIC IMPACT ANALYSIS. The survey data were analyzed to compute descriptive statistics for each variable, including the mean, sE, number of respondents, and sum of sample values. Information on annual sales was reported by $79 \%$ of nurseries, $77 \%$ of landscape firms, and $55 \%$ of retailers surveyed. Total annual sales for each firm was estimated at the midpoint value of the

Table 1. Sample size and expansion factors for survey of the Florida environmental horticulture industry.

\begin{tabular}{|c|c|c|c|c|c|c|c|c|c|}
\hline \multirow[b]{2}{*}{ Industry sector } & \multirow{2}{*}{$\begin{array}{c}\text { Firms in } \\
\text { Florida } \\
\text { (no.) }\end{array}$} & \multicolumn{3}{|c|}{ Firms surveyed (no.) } & \multirow{2}{*}{$\begin{array}{c}\text { Firms } \\
\text { qualified }^{\mathrm{z}} \\
(\%)\end{array}$} & \multirow{2}{*}{$\begin{array}{c}\text { Firms } \\
\text { reporting } \\
\text { sales (\%) }\end{array}$} & \multirow{2}{*}{$\begin{array}{c}\text { Sales } \\
\text { expansion } \\
\text { factor }^{\mathrm{y}}\end{array}$} & \multirow{2}{*}{$\begin{array}{c}\text { Firms } \\
\text { reporting } \\
\text { employment }(\%)\end{array}$} & \multirow{2}{*}{$\begin{array}{c}\text { Employment } \\
\text { expansion } \\
\text { factor }^{y} \\
\end{array}$} \\
\hline & & Internet & Telephone & Total & & & & & \\
\hline Landscape services & 8,467 & 65 & 126 & 191 & 32.3 & 77.0 & 18.6 & 96.3 & 14.9 \\
\hline $\begin{array}{l}\text { Horticultural } \\
\text { retailers }\end{array}$ & 7,359 & 9 & 204 & 213 & 48.7 & 54.9 & 30.6 & 90.6 & 18.6 \\
\hline
\end{tabular}

${ }^{2}$ Firms with valid contact in telephone survey

'Expansion factors were multiplied against survey sample sums to estimate total sales and employment for the entire Florida population of business firms; these factors were derived from the percentages of surveyed firms qualified together with the percentages of firms reporting sales or employment, respectively.

Table 2. Employment in the Florida environmental horticulture industry in 2005.

\begin{tabular}{|c|c|c|c|c|c|c|}
\hline \multirow[b]{2}{*}{ Industry sector } & \multicolumn{3}{|c|}{$\begin{array}{l}\text { Employment reported by survey } \\
\text { respondents (no. of jobs) }\end{array}$} & \multicolumn{3}{|c|}{$\begin{array}{l}\text { Total industry employment } \\
\text { (no. of jobs) })^{\mathrm{z}}\end{array}$} \\
\hline & Full-time & Part-time & Total & Full-time & Part-time & Total \\
\hline Landscape services & 4,004 & 1,537 & 5,541 & 59,513 & 28,402 & 87,914 \\
\hline Horticultural retailers & 5,666 & 3,476 & 9,142 & 105,212 & 66,617 & 171,830 \\
\hline Total & 15,900 & 6,594 & 22,494 & 190,384 & 103,795 & 294,179 \\
\hline
\end{tabular}

${ }^{\mathrm{z}}$ Estimated based on survey expansion factors 
range selected, unless a specific value was reported. Sales of specific products or services and sales by market segment or region were estimated from the reported share of total sales by each firm. Expanded estimates of total sales and employment in each industry sector were based on the sample sales or employment reported, the number of firms reporting this information, the population of firms, and the percentage of firms qualified for the telephone survey according to the disposition of calls. Survey sample numbers and expansion factors for each industry sector are shown in Table 1. Expansion factors for the nursery sector were computed separately by firm size class based on plant inventory numbers reported by the Florida Division of Plant Industry: small (1000 to 5000 plant units), medium (5001 to 50,000$)$, large $(50,001$ to 500,000$)$, and very large (over 500,000). Sales expansion factors were 5.5 for nurseries, 18.6 for landscape firms, and 30.6 for retail firms, whereas employment expansion factors were 4.6, 14.9, and 18.6, respectively.

Economic impacts were estimated using a regional input-out model and social accounting matrix developed using the IMPLAN Pro software and associated 2003 databases for Florida (Minnesota IMPLAN Group, 1997, 2006). The IMPLAN databases consist of a set of socioeconomic accounts that describe the structure of the U.S. economy in terms of transactions between households, governments, and 509 industry sectors classified on the basis of the primary commodity or service produced according to the North American Industry Classification System.

Table 3. Sales by the Florida environmental horticultural industry in 2005.

\begin{tabular}{lcc}
\hline $\begin{array}{l}\text { Industry } \\
\text { sector }\end{array}$ & $\begin{array}{c}\text { Value } \\
\text { reported } \\
(\text { million } \$)\end{array}$ & $\begin{array}{c}\text { Expanded } \\
\text { value } \\
\text { million } \$)^{\mathbf{z}}\end{array}$ \\
$\begin{array}{l}\text { Nursery and } \\
\text { greenhouse }\end{array}$ & 521.9 & $3,007.2$ \\
$\begin{array}{l}\text { Landscape } \\
\text { services }\end{array}$ & 264.8 & $5,258.5$ \\
$\begin{array}{l}\text { Horticultural } \\
\text { retailers }\end{array}$ & 134.0 & $6,970.9$ \\
Total & 920.7 & $15,236.6$ \\
\hline
\end{tabular}

${ }^{\mathrm{z}}$ Estimated based on survey sample expansion factors.

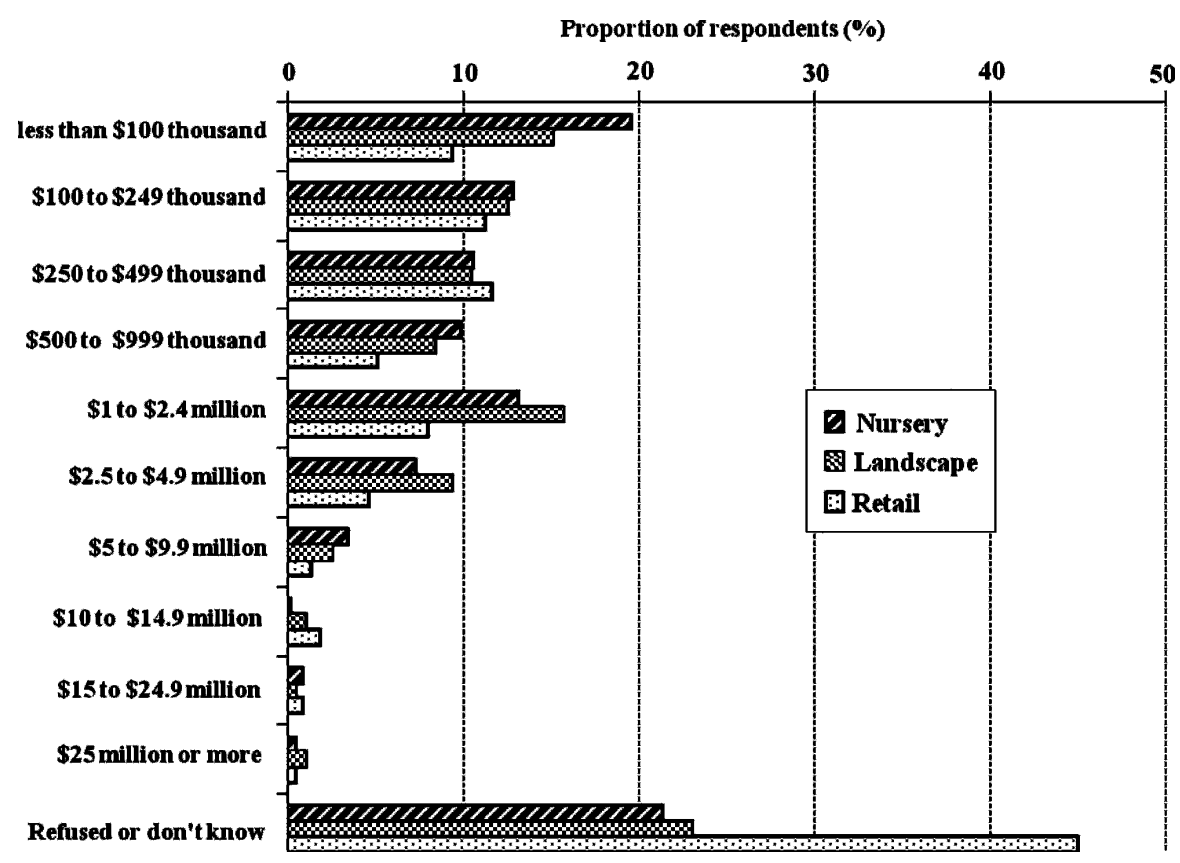

Fig. 1. Distribution of Florida environmental horticulture industry survey respondents by annual sales class.

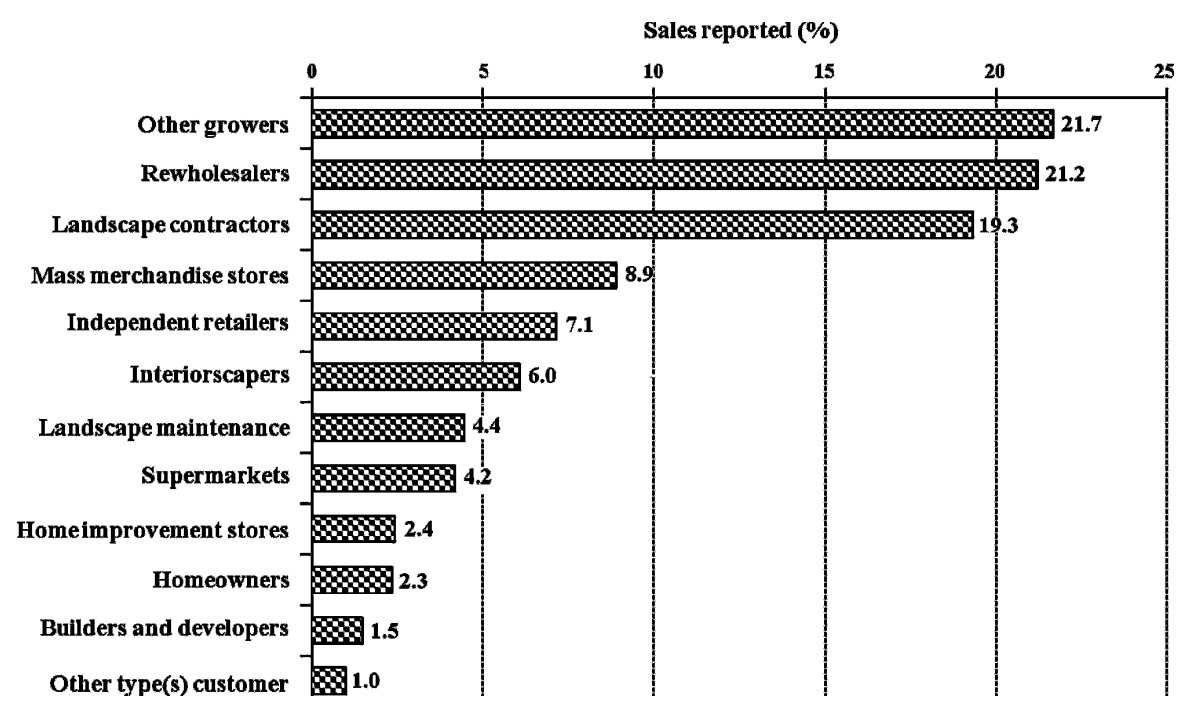

Fig. 2. Distribution of customer sales by Florida nurseries in 2005.

The databases also describe local or regional economies in terms of industry output, value added, employment, imports, and exports. An IMPLAN model for Florida was constructed with all social accounts included and all parameters set at default values. Economic multipliers for output (revenue), employment, value added, labor income, and indirect business taxes were compiled for each sector of the horticulture industry in Florida. The multipliers capture overall effects of economic activity in the horticulture industry, including activity in the supply chain by vendors selling inputs to the industry (indirect effects) and the spending by industry employees (induced effects). The magnitude of the multipliers represents the strength of linkages in the regional economy to other sectors and institutions and the share of total inputs provided to industry firms by other businesses within the region.

Economic impacts of each sector of the horticultural industry were calculated using the direct effects multiplier on local or in-state sales and the indirect and induced effects multipliers on nonlocal or out-ofstate sales. Nonlocal (export) sales 


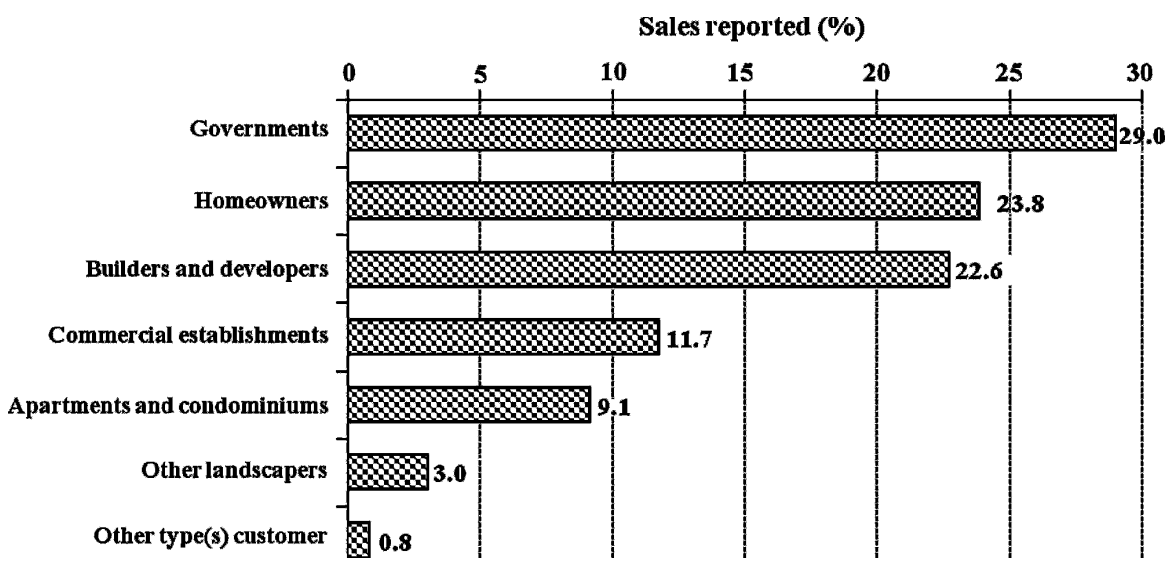

Fig. 3. Distribution of customer sales by Florida landscape service firms in 2005.

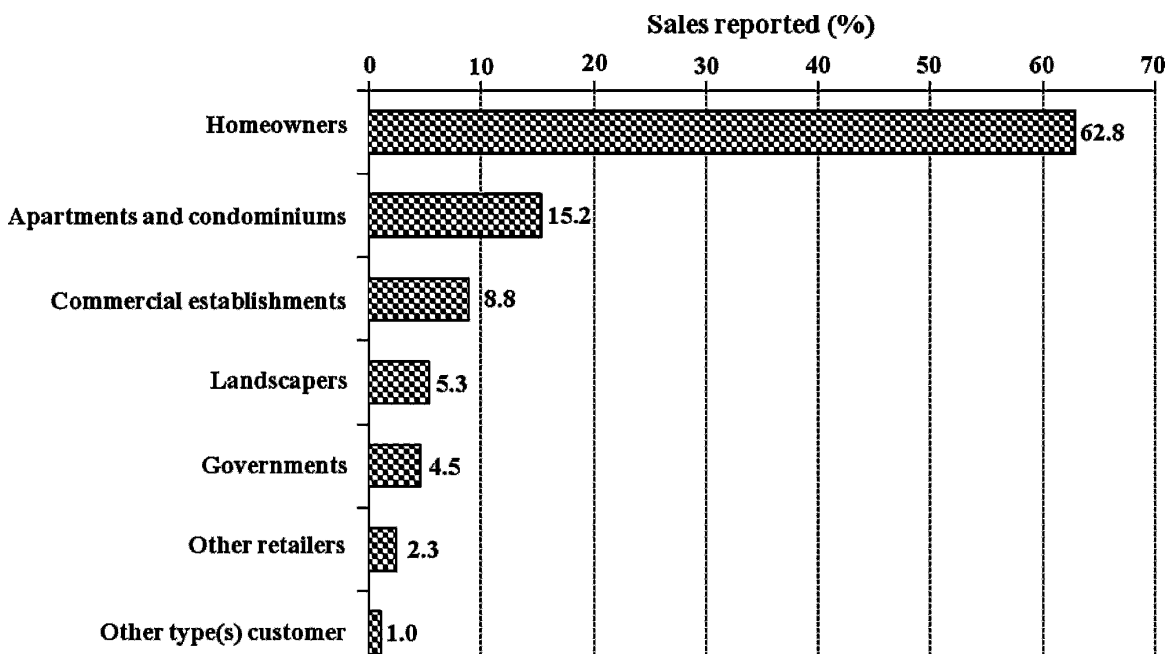

Fig. 4. Distribution of customer sales by Florida horticultural retailers in 2005.

were treated differently because they bring "new" money into the local economy to expand economic activity. Total employment impacts were estimated from survey data for the direct effects and from multipliers for the indirect and induced effects. Output of the retail sector was taken as the gross margin, $\approx 30 \%$ of sales, using the Annual Benchmark Report for Retail Trade (U.S. Dept. of Commerce, 2004). All values for previous periods were expressed in 2005 dollars using the gross domestic product implicit price deflator (U.S. Dept. of Commerce, 2006).

\section{Results}

EMployment. The number of jobs generated by a firm or industry is a fundamental measure of its economic contribution to a regional economy. Surveyed firms in the environmental horticulture industry in
Florida reported direct employment of 22,494 persons in 2005 , including 7811 employees in nurseries, 5541 in landscape services, and 9142 by horticultural retailers (Table 2). Approximately $65 \%$ of all jobs were full-time positions and $35 \%$ were for part-time, temporary, or seasonal positions. Part-time employment was reported by $81 \%$ of nurseries, $78 \%$ of landscape firms, and $88 \%$ of retailers. Based on the expansion factors discussed previously, total industry employment was estimated at 294,179 jobs, including 34,435 for nurseries, 87,914 for landscape services, and 171,830 for retailers.

SALES OF PRODUCTS AND SERvices. Total sales in 2005 reported by surveyed Florida firms were $\$ 921 \mathrm{M}$ and expanded total industry sales were estimated at $\$ 15.24 \mathrm{~B}$, including $\$ 3.01 \mathrm{~B}$ by nurseries, $\$ 5.25 \mathrm{~B}$ by landscape service firms, and $\$ 6.97 \mathrm{~B}$ by horticultural retailers (Table 3 ). Respondents reporting annual sales of less than $\$ 500,000$ represented $42 \%$ of nurseries, $38 \%$ of landscape firms, and $32 \%$ of retailers surveyed, whereas those with annual sales exceeding $\$ 10 \mathrm{M}$ were $1.6 \%, 2.5 \%$, and $3.3 \%$, respectively (Fig. 1).

Sales of horticultural products and services to different types of customers were also evaluated. For nurseries, the most important customers were other growers, representing 22\% of total sales, rewholesalers or brokers $(21 \%)$, and landscape contractors (19\%), then mass merchandise stores $(9 \%)$, independent retail garden centers $(7 \%)$, and interiorscapers $(6 \%)$ (Fig. 2). For landscape firms, the most important customer segments were governments (29\%), homeowners $(24 \%)$, builders and developers $(23 \%)$, commercial establishments $(12 \%)$, and apartments and condominiums (9\%) (Fig. 3). For

Table 4. Economic impacts of the Florida environmental horticulture industry in 2005.

\begin{tabular}{|c|c|c|c|c|c|c|c|c|c|}
\hline Industry sector & $\begin{array}{c}\text { Direct } \\
\text { output } \\
\text { (million } \$)\end{array}$ & $\begin{array}{c}\text { Non-local } \\
\text { output } \\
\text { (million \$) }\end{array}$ & $\begin{array}{c}\text { Indirect } \\
\text { output } \\
\text { impact } \\
\text { (million\$) }\end{array}$ & $\begin{array}{c}\text { Induced } \\
\text { output } \\
\text { impact } \\
(\text { million\$) }\end{array}$ & $\begin{array}{c}\text { Total } \\
\text { output } \\
\text { impact } \\
(\text { million } \$)\end{array}$ & $\begin{array}{c}\text { Employment } \\
\text { impact } \\
\text { (jobs) }\end{array}$ & $\begin{array}{c}\begin{array}{c}\text { Value- } \\
\text { added } \\
\text { impact } \\
(\text { million \$) }\end{array} \\
\end{array}$ & $\begin{array}{c}\text { Labor } \\
\text { income } \\
\text { impact } \\
(\text { million } \$) \\
\end{array}$ & 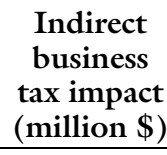 \\
\hline $\begin{array}{l}\text { Nursery and } \\
\text { greenhouse }\end{array}$ & $3,007.9$ & $1,270.4$ & 34.7 & $1,725.4$ & $4,768.0$ & 53,551 & $3,977.9$ & $1,847.9$ & 125.4 \\
\hline Landscape services & $5,258.5$ & 9.0 & 3.7 & 10.7 & $5,273.0$ & 88,073 & $2,718.2$ & $2,161.1$ & 93.2 \\
\hline
\end{tabular}


Table 5. Comparison of economic impacts of the Florida environmental horticulture industry in 1997, 2000, and 2005.

\begin{tabular}{|c|c|c|c|c|}
\hline Impact/sector & 2005 & 2000 & 1997 & $\begin{array}{c}\text { Avg annual } \\
\text { growth rate (\%) }\end{array}$ \\
\hline Sales (million \$) & 15,237 & 11,120 & 8,353 & 7.8 \\
\hline Landscape services & 5,259 & 3,491 & 3,185 & 6.5 \\
\hline Horticultural retailers & 6,971 & 5,103 & 3,005 & 11.1 \\
\hline Output impacts (million \$) & 12,637 & 10,285 & 8,173 & 5.6 \\
\hline Horticultural retailers & 2,596 & 2,574 & 1,678 & 5.6 \\
\hline Value-added impacts (million $\$$ ) & 8,648 & 7,184 & 5,973 & 4.7 \\
\hline Nursery and greenhouse & 3,978 & 2,826 & 2,238 & 7.5 \\
\hline Landscape services & 2,718 & 2,391 & 2,502 & 1.0 \\
\hline Horticultural retailers & 1,952 & 1,968 & 1,234 & 5.9 \\
\hline
\end{tabular}

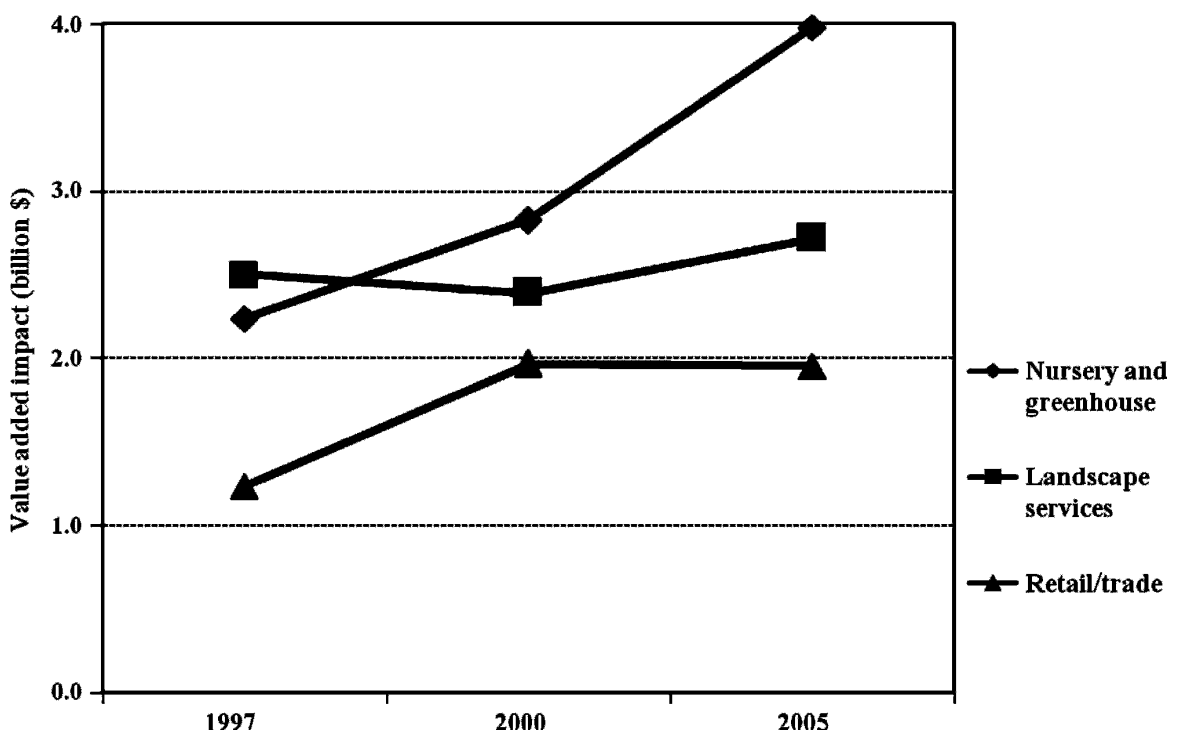

Fig. 5. Trend in value-added impacts of the Florida environmental horticulture industry from 1997 to 2005 . Values expressed in 2005 dollars.

horticultural retailers, the dominant market segment was homeowners, representing $63 \%$ of total sales, followed by apartments and condominiums (15\%) and commercial establishments (9\%) (Fig. 4).

Economic IMPACTS. The total output or revenue impact of the Florida environmental horticulture industry in 2005 was estimated at $\$ 12.64$ $\mathrm{B}$, including $\$ 10.39 \mathrm{~B}$ in direct output impacts of industry sales plus $\$ 100 \mathrm{M}$ in indirect impacts from allied firms that supply inputs to the horticulture sectors and \$2.15 B in induced impacts associated with consumer spending by industry employee households (Table 4). Total output impacts were $\$ 4.77 \mathrm{~B}$ for nurseries, $\$ 5.27$ B for landscape services firms, and \$2.60 B for horticultural retailers. Nurseries had significant indirect and induced impacts associated with the large nonlocal sales. The total employment impact of the industry was 318,573 jobs, including both full-time and part-time/seasonal, with 53,551 for nurseries, 88,073 for landscape services, and 176,949 for horticultural retailers.

Value added is an important measure of the net economic contribution to business and personal income in a regional economy; specifically, it is the difference between sales revenues and the cost of purchased inputs and includes the value of employee wages and benefits, owner's compensation, dividends, capital outlays, and business taxes paid. The total value-added impact of Florida's horticulture industry in 2005 was $\$ 8.65 \mathrm{~B}$, with $\$ 3.98 \mathrm{~B}$ by nurseries, $\$ 2.72$ B by landscape services, and $\$ 1.95 \mathrm{~B}$ by retailers. The greater value-added impact of nurseries is because they create a product from raw materials, thereby adding value, in contrast to retailers who primarily distribute the product to consumers. Also, unlike retailers and landscape firms, nurseries export a large share of their product outside the state, bringing "new money" into the region, which stimulates greater economic activity through the multiplier effects. Total labor income impacts, which are a subset of value added, were \$5.19 B. The impact on indirect business taxes paid to state and local governments was $\$ 549 \mathrm{M}$.

INDUSTRY TRENDS 1997 TO 2005. The economic impacts of the Florida environmental horticulture industry in 2005 were compared with results from previous studies conducted in 1997 and 2000 using similar methods to assess trends in financial performance over time. Total industry sales increased from $\$ 8.35 \mathrm{~B}$ in 1997 to $\$ 15.24 \mathrm{~B}$ in 2005 in inflation-adjusted terms, which represented a $7.8 \%$ average annual compound growth rate during the 8 -year period (Table 5 ). The total output impact increased from $\$ 8.17 \mathrm{~B}$ in 1997 to $\$ 12.64 \mathrm{~B}$ in 


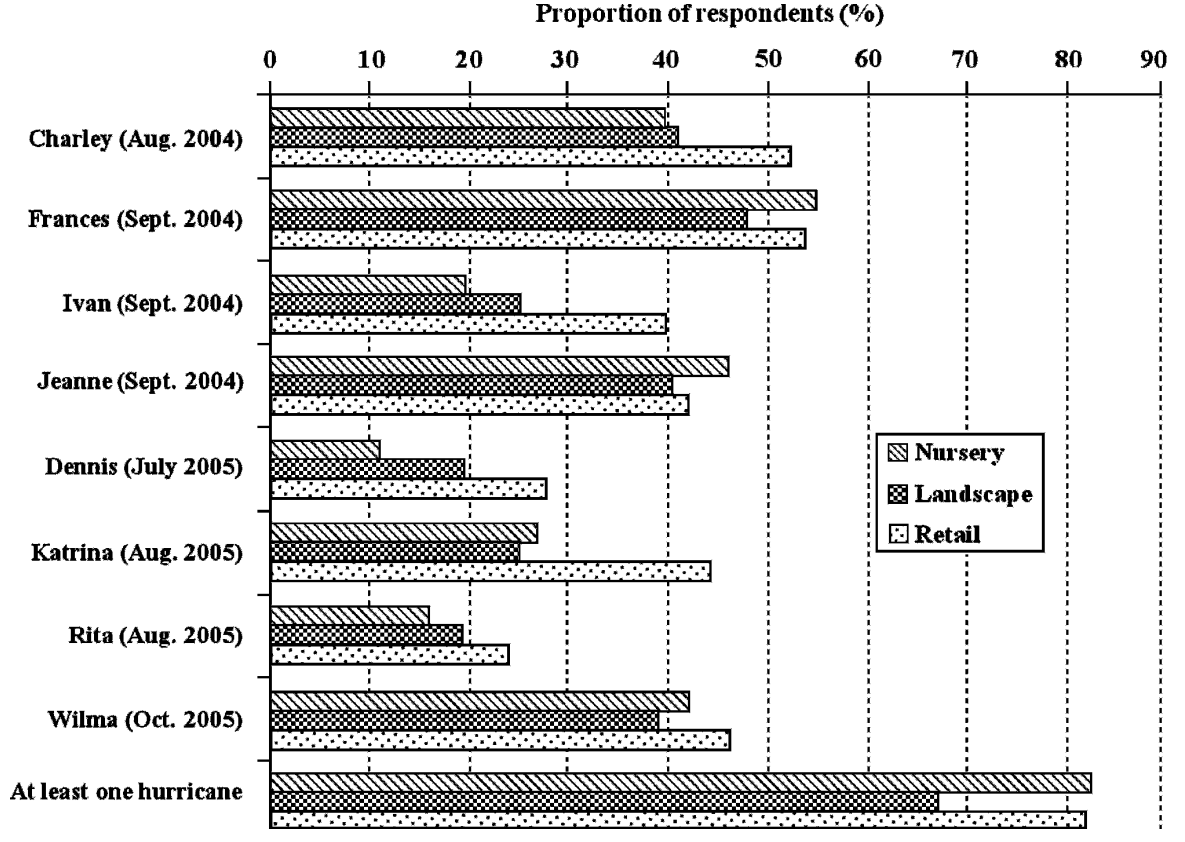

Fig. 6. Florida environmental horticulture industry firms adversely affected by hurricanes in 2004 and 2005 .

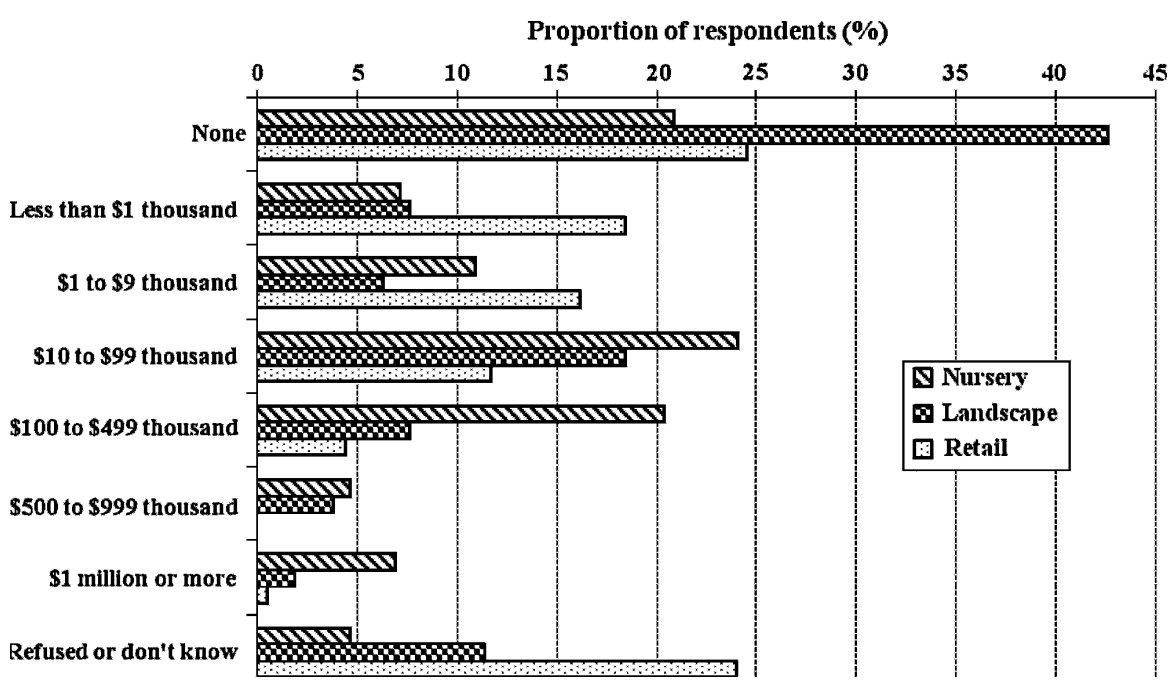

Fig. 7. Distribution of product (crop) losses to Florida environmental horticulture industry firms resulting from hurricanes in 2004 and 2005.

2005, representing an average annual growth rate of $5.6 \%$. Industrywide value-added impacts grew from $\$ 5.97$ to $\$ 8.65 \mathrm{~B}$, or $4.7 \%$ annually. Average annual sales growth during the study period was significantly higher for the retail sector $(11.1 \%)$ than for landscape services $(6.5 \%)$ and nurseries $(4.2 \%)$; however, in terms of output and value-added impacts, there was less divergence among industry sectors (Fig. 5). Growth in sales between 2000 and 2005 was slightly lower at $6.5 \%$ annually, reflecting the nursery workers. Overall, employment by the environmental horticulture industry is now larger than any other sector in Florida agriculture.

In general, the rapid growth experienced by the environmental horticulture industry was driven largely by Florida's expanding population and increasing affluence. New development brings about increased demand for nursery products, landscape design, and building services, whereas existing property owners also purchase nursery products and associated goods from retail garden stores for landscape renovations and improvements. Many new developments feature greater amenities, including more creative landscaping, which contributes to the appeal and resale value of the property. An increasing share of homeowners and commercial businesses contract with landscape service firms for the ongoing care and maintenance of their properties. Finally, a wider range of retail establishments have made horticultural goods more available and affordable to the public than ever before.

IMPACTS OF HURRICANES IN 2004 AND 2005. The state of Florida was struck by an unprecedented series of eight major hurricanes during 2004 and 2005. These storms did tremendous damage to infrastructure, caused large losses of products for sale, and interrupted business activity throughout the state's economy, particularly the agricultural sector. Nearly $80 \%$ of survey firms in the environmental horticulture industry indicated that they were adversely impacted by at least one of these hurricanes, including $83 \%$ of nurseries, $67 \%$ of landscape firms, and $82 \%$ of horticultural retailers (Fig. 6). The largest numbers of industry firms were affected by hurricanes named Frances (53\%), Jeanne (44\%), Charley $(43 \%)$, and Wilma (42\%).

Survey respondents reported losses of products (crops), structural damages to buildings and equipment, cleanup costs, and length of business interruption. Losses of products for sale valued at $\$ 100,000$ or more were reported by $22 \%$ of all firms, whereas losses of at least $\$ 1 \mathrm{M}$ were reported by $4 \%$ of firms, including $7 \%$ of nurseries (Fig. 7). Structural damages of at least $\$ 100,000$ were sustained by $12 \%$ of firms (Fig. 8). Cleanup costs of at 
least $\$ 100,000$ were reported by $8 \%$ of firms (Fig. 9). Nearly half (49\%) of firms had their business interrupted for 3 weeks or more (Fig. 10).

The total hurricane damages incurred by industry firms in Florida during 2004 and 2005 were estimated from damages reported by survey respondents together with expansion factors, assuming losses to be at the midpoint of the range of values selected. Estimated total damages amounted to $\$ 2.12 \mathrm{~B}$, including product losses of $\$ 1.05 \mathrm{~B}$, structural damages of $\$ 465 \mathrm{M}$, and cleanup costs of $\$ 605 \mathrm{M}$ (Table 6). Total losses were $\$ 964 \mathrm{M}$ for nurseries, $\$ 675 \mathrm{M}$ for landscape firms, and $\$ 482 \mathrm{M}$ for retailers.

\section{Conclusions}

This study documented sales and employment in 2005 by Florida nursery growers, landscape service firms, and horticultural retailers; estimated regional economic impacts using an IMPLAN model; and compared results with previous studies to assess trends in the industry. The research demonstrated that the environmental horticulture industry in Florida has continued to grow rapidly during the period of 1997 through 2005 driven by strong population growth and housing development. Growth was particularly strong for the retail sector. Industry sales and employment estimated from survey data were significantly higher than other published values and statistics reported by the Florida Department of Labor, Quarterly Census of Employment and Wages, as a result of better coverage of many small and undocumented firms. The nursery production sector has significant indirect and induced impacts on other sectors of the economy associated with sales of plant products to out-of-state markets that bring new money into the state. Total employment impacts of the environmental horticulture industry in Florida were significantly greater than for other major agricultural commodities such as forest products and fruits/ vegetables, whereas total output and value-added impacts were comparable. Unlike many other agricultural industries, economic activity in environmental horticulture in Florida tends to be concentrated in urban areas, close to the workforce and

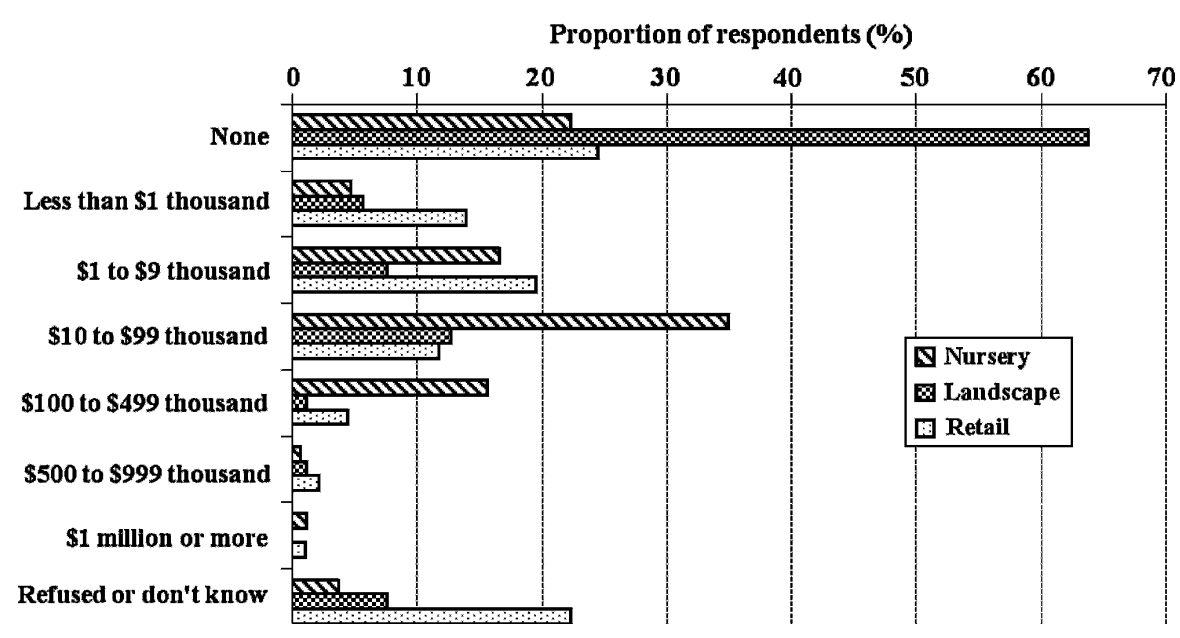

Fig. 8. Distribution of structural damages to Florida environmental horticulture industry firms resulting from hurricanes in 2004 and 2005.

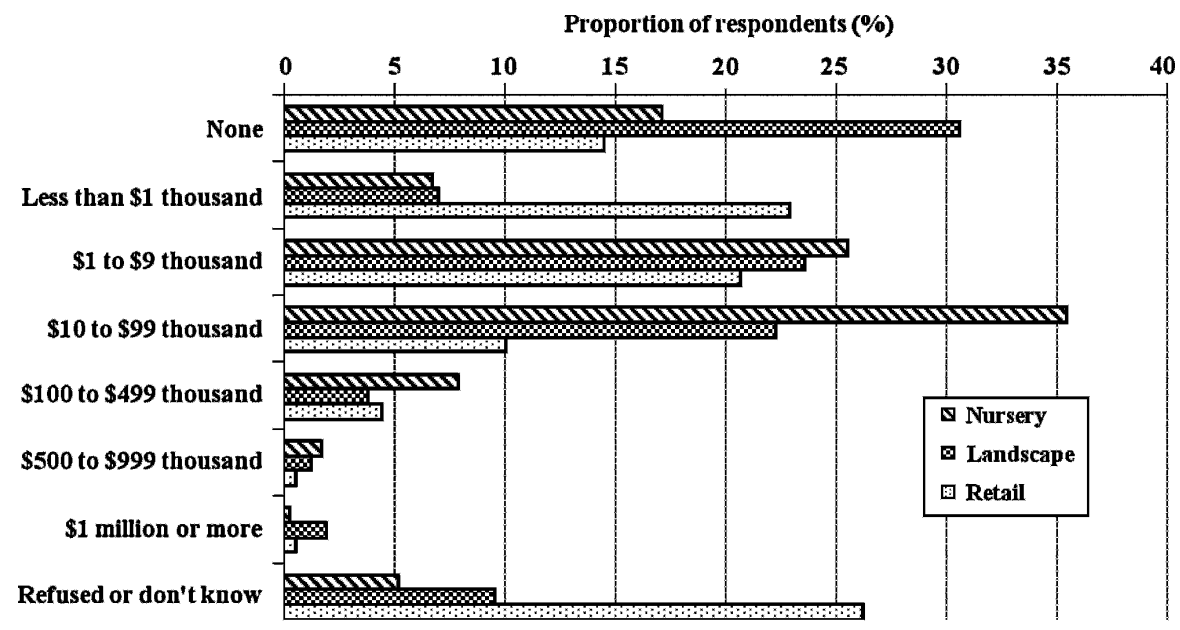

Fig. 9. Distribution of cleanup costs to Florida environmental horticulture industry firms resulting from hurricanes in 2004 and 2005.

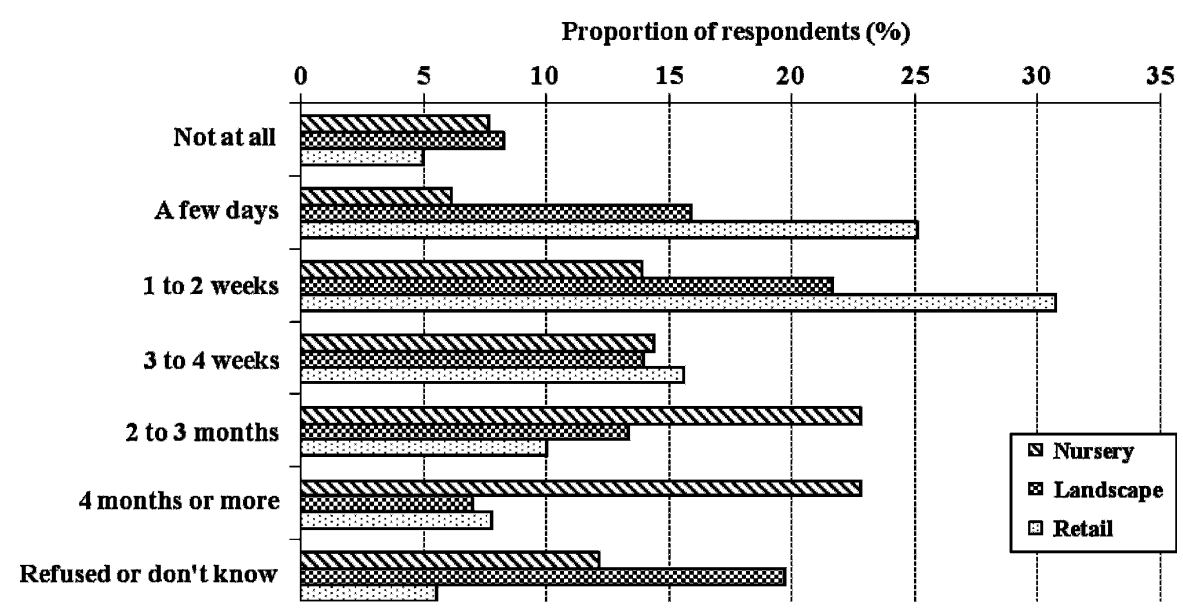

Fig. 10. Distribution of length of business interruption to Florida environmental horticulture industry firms resulting from hurricanes in 2004 and 2005.

markets for landscape services and retail goods. The economic impacts of the environmental horticulture industry occurred despite the stagages, cleanup costs, and business gering product losses, structural dam- 
Production and Marketing Reports

Table 6. Estimated losses by the Florida environmental horticulture industry resulting from hurricanes in 2004 and 2005.

\begin{tabular}{|c|c|c|c|c|}
\hline Type of loss & $\begin{array}{l}\text { Nursery and } \\
\text { greenhouse }\end{array}$ & $\begin{array}{c}\text { Landscape } \\
\text { services }\end{array}$ & $\begin{array}{c}\text { Horticultural } \\
\text { retailers }\end{array}$ & $\begin{array}{c}\text { All } \\
\text { sectors }\end{array}$ \\
\hline Proc & 65 & 27 & & 04 \\
\hline Structural damage & 183.3 & 61.2 & 220.6 & 465.4 \\
\hline Cleanup costs & 121.5 & 340.5 & 143.3 & 605.3 \\
\hline Total & 964.3 & 674.8 & 481.8 & 2120.9 \\
\hline
\end{tabular}

interruption suffered from hurricanes in 2004 and 2005.

\section{Literature cited}

Berrens, R.P., A.K. Bohara, H. JenkinsSmith, C. Silva, and D.L. Weimer. 2003. The advent of internet surveys for political research: A comparison of telephone and Internet samples. Polit. Anal. 1:1-22.

Hall, C.R., A.W. Hodges, and J.J. Haydu. 2006. Economic impacts of the green industry in the United States. HortTechnology 16:345-353.

Hodges, A.W. and J.J. Haydu. 2000. Economic impact of Florida's environ- mental horticulture industry. J. Environ. Hort. 18:123-127.

Hodges, A.W. and J.J. Haydu. 2002. Economic impacts of the Florida environmental horticulture industry, 2000. University of Florida-Institute of Food and Agricultural Sciences, Food and Resource Economics Department, Economic Info. Rpt. EI02-3.

Hodges, A.W. and W.D. Mulkey. 2006. Economic impacts of agriculture and natural resource industries in Florida 2003. University of Florida-Institute of Food and Agricultural Sciences, Ext., Document FE627.

Jerardo, A. 2005. Floriculture and nursery crops situation and outlook. FLO-2005.
U.S. Dept. Agriculture, Economic Research Service, Washington, DC.

Minnesota IMPLAN Group. 1997. IMPLAN professional social accounting and impact analysis software, user's guide, analysis guide and data guide, 2 nd ed. Minnesota IMPLAN Group, Stillwater, MN.

Minnesota IMPLAN Group. 2006. IMPLAN 2003 state data package for Florida. Minnesota IMPLAN Group Stillwater, MN.

U.S. Dept. of Agriculture. 2004. Census of agriculture, 2002. Florida state and county data, vol. 1, Geographic area series, Part 9, AC-02-A-9. National Agricultural Statistics Service, Washington, DC.

U.S. Dept. of Commerce. 2004. Annual benchmark report for retail trade and food services: Jan. 1992 through Feb. 2004. Current Business Rpt. BR/03-A. Census Bureau, Washington, DC.

U.S. Dept. of Commerce. 2006. Gross domestic product implicit price deflator, 1970-2005, annual. 1 Aug. 2006. <http://research.stlouisfed.org/fred/ data/gdp/gdpdef $>$. 